\title{
İşlem Bazlı Manipülasyon: Türkiye Örneği ${ }^{\mathrm{a}}$
}

\author{
Trade-Based Manipulation: The Case of Turkey ${ }^{b}$
}

\author{
Eray GEMICi' ${ }^{1}$, Mehmet CIHANGIR ${ }^{2}$, Emre YAKUT ${ }^{3}$
}

\begin{abstract}
ÖZET
$\mathrm{Bu}$ çalışmada sermaye piyasası üzerinde gerçekleştirilen manipülasyon türlerinden olan işlem bazlı manipülasyon incelenmiştir. Çalışmanın veri seti 2001-2014 dönemi arasında Borsa İstanbul'da (BIST) kota olan ve SPK tarafindan manipülasyon gerçekleştirdiği tespit edilen şirketlerden hareketle 273 manipülasyon vakası ele alınmıştır. Şirketler tarafından gerçekleştirilen manipülasyonun etkisine yönelik günlük bazda; getiri, işlem hacmi, volatilite ve pay senedi devir hızı değişkenleri kullanılmıştır. Sınıflandırma işlemi; manipülasyon öncesi, manipülasyon dönemi ve manipülasyon sonrası dönem dikkate alınarak gerçekleştirilmiştir. Çoklu lojistik regresyon analizi sonucunda değişkenlerin tamamını istatistiksel açıdan anlamlı olduğu tespit edilmiş ayrıca günlük getiri ve volatilite değişkenlerinin manipülasyon üzerinde daha çok etkiye sahip olduğu tespit edilmiştir.
\end{abstract}

Anahtar kelimeler: İşlem bazlı manipülasyon, Sermaye piyasası, Çoklu lojistik regresyon

\section{GíRiş}

Pay senedi piyasalarında gözlemlenen ve zararlı uygulamalar arasında gösterilen piyasa manipülasyonu, yapay fiyat hareketleri yaratarak arz ve talebi ve sonuç olarak pay senedi fiyatının adil bir şekilde oluşmasını engellemekte ve yatırımcıların piyasaya olan güvenlerini zedelemektedir. Yasal bağlamda ülkelerin piyasa düzenleyici kurumları piyasaya zarar veren bu tip eylemleri yasaklamakta ve bu eylemleri gerçekleştirenlere karşı ciddi yaptırımlar uygulamaktadır. Nitekim piyasa manipülasyonu

\begin{abstract}
In this study one of the manipulation types in the capital market, namely the trade-based manipulation was investigated. Data set for the study was gathered from 273 manipulation cases which were examined with reference to the companies detected by SPK (Capital Markets Board) to have manipulated the markets and quoted in Borsa istanbul (BIST) in the period between 2001-2014. For the effect of manipulations by the companies, variables of daily return, trading volume, volatility and stock turnover rate were used. The process was classified as pre-manipulation period, manipulation period and post manipulation period. As a result of the study, according to the multiple logistic regression, all variables were found to be statistically significant; moreover, it was also found that daily return and volatility variables have more effect on manipulation.
\end{abstract}

Keywords: Trade-based manipulation, Capital markets, Multiple logistic regression.

hakkında Amerika Birleşik Devletleri'ndeki 1934 tarihli menkul kıymetlerin alımı ve satımına ilişkin kanunun ilgili bölümü; kamunun çıkarına uygun veya yatırımcıların korunmasında gerekli olarak kuralları ihlal ederek menkul kıymetin satın alınmasıyla veya satılmasıyla ilgili herhangi bir manipülatif eylemi yasaklamış ve tüm dünyada manipülasyonun yasal zeminde ilgili otoritelerin dikkate alması gerektiği yönünde itici bir güç olmuştur.

Piyasa manipülasyonun ilk örnekleri, pay senetlerinin fiyatını etkilemek üzere yanlış dedikodular veya

aBu makale, "Pay piyasasında manipülasyonların incelenmesi: Borsa İstanbul'da bir uygulama" adlı doktora tezinden üretilmiştir.

${ }^{b}$ This paper is based on a PhD study titled "The analysis of manipulations in equity market: An application in Istanbul Stock Exchange."

'Yrd. Doç. Dr., Gaziantep Üniversitesi, gemici@gantep.edu.tr

2Doç.Dr., Osmaniye Korkut Ata Üniversitesi, cihangir@osmaniye.edu.tr.

${ }^{3}$ Yrd. Doç. Dr., Osmaniye Korkut Ata Üniversitesi, emreyakut@osmaniye.edu.tr 
başka yanıltıcı bilgiler yaymak gibi kurgulardan oluşan bilgiye dayalı manipülasyon olarak ifade edilirken, 19 'ncu yüzyılın sonuna doğru piyasa manipülasyonu kavramı, dedikodu ve yanlış veya yanıltıcı bilgi olmadan sadece işlem yoluyla yapılan manipülasyonu içerecek şekilde genişletilmiştir (Constable, 2011).

Uluslararası Menkul Kıymet Komisyonları Örgütü (IOSCO) tarafından yayımlanan "Piyasa Manipülasyonunun Araştırılması ve Yasal Uygulaması" isimli raporda manipülatörlerin kullandıkları yaygın manipülatif yöntemler şu şekilde sıralanmıştır (IOSCO, 2000):

- Tahtayı boyamak (painting the tape)

- Kendinden kendine işlemler (wash sales)

- Uygun olmayan eşleştirilmiş emirler (impropered matched orders)

- Alım teklifini yükseltme (advancing the bid)

- Pompalama ve şişirme (pumping and dumping)

- Pay senedinin kapanış fiyatını belirleme (marking the close)

- Piyasayı köşeye sıkıştırma (corner)

- Baskı oluşturma (squezee)

Fischel ve Ross (1991), manipülasyonu; menkul kıymetler piyasasında oluşan arz ve talebe kasıtlı bir biçimde müdahale edilmesi olarak tanımlamış ve manipülatif davranış kalıbının üç şekilde gerçekleştiğini belirtmiştir. Bunlar:

- Serbest bir şekilde oluşan arz ve talebe müdahale etmek,

- İnsanları alım satım yapmaya teşvik etmek,

- Bir menkul kıymetin fiyatının yapay bir seviyeye gelmesi için baskı yapmak.

Allen ve Gale (1992), manipülasyonu; hareket bazlı manipülasyon, bilgi bazlı manipülasyon ve işlem bazlı manipülasyon olmak üzere üç grupta sınıflandırmıştır. Brouwer (2001), hareket bazlı manipülasyonu; varlıkların gerçek veya algılanan değerini değiştiren hareketler olarak tanımlamıştır. Yönetimin pay senedi fiyatını düşürecek bir karar alarak (örneğin kar eden bir fabrikayı kapatma kararı) fiyatı düşen pay senedinden mümkün olduğunca çok sayıda satın alması ve daha sonra aldığı bu kararı geri çekmesi, hareket bazlı manipülasyonun klasik bir örneğini oluşturmaktadır (Korsmo, 2013). Bilgiye dayalı manipülasyon ise yanlış bilgi veya yanıltıcı söylentiler yayarak gerçekleştirilmektedir. Bunun en tipik örneği 1920'lerde ABD'de işlem havuzları olarak bilinen uygulamalardır. Burada bir yatırımcı grubu öncelikle bir pay senedini satın almakta ve daha sonra firma hakkında olumlu söylentiler yayarak belirli bir kar düzeyinde bu pay senetlerini satmak üzere bir havuz oluşturmaktadır (Mei vd. 2004).

Bu çalışmanın konusunu oluşturan işlem bazlı manipülasyon, 2012 yılında yürürlüğe giren 6362 sayılı yeni Sermaye Piyasası Kanunu (SPKn)'nun 107'nci maddesinin birinci fıkrasında işlem bazlı piyasa dolandırıcılığı olarak düzenlenmiş ve "Sermaye piyasası araçlarının fiyatlarına, fiyat değişimlerine, arz ve taleplerine ilişkin olarak yanlış veya yanıltıcı izlenim uyandırmak amacıyla alım veya satım yapanlar, emir verenler, emir iptal edenler, emir değiştirenler veya hesap hareketleri gerçekleştirenler" hakkında 2 yıldan 5 yıla kadar hapis ve beş bin günden on bin güne kadar adli para cezası verileceği hükme bağlanmıştır.

Literatürde manipülasyon konusunda yapılan ampirik çalışmalar, gerekli olan işlem seviyesindeki verilerin gizli bilgi olarak görülmesi ve akademisyenlerin bu verilere ancak sınırlı bir seviyede ulaşabilmelerinden dolayı yetersiz kalmaktadır (Özcan, 2013). Bu sebeple bu çalışmanın temel amacı, Türkiye'deki bu alanda yapılan çalışmaları da göz önüne alarak Borsa İstanbul'da 2001-2014 döneminde gerçekleştirilen işlem bazlı manipülatif işlemlerin pay piyasasındaki etkilerini manipülasyon yapmış her bir şirket için günlük bazda olmak üzere; pay senedi getirisi, işlem hacmi, volatilite, pay senedi devir hızı ve payın dahil olduğu endeks getiri verileri yardımıyla analiz etmektir. Diğer taraftan yurt dışında yapılan çalışmalarda işlem bazlı manipülasyon üzerinde etkili olduğu tespit edilen fakat ülkemizde etkisi incelenmeyen pay senedi devir hızı değişkeninin etkisinin ortaya konması çalışmanın bir diğer amacını oluşturmaktadır.

\section{LITERATÜR ÖZETi}

Allen ve Gale (1992), işlem bazlı manipülasyonu teorik çerçevede inceledikleri çalışmada, pay senedinin gelecekteki değeri hakkında iyi bilgi sahibi olmayan bir spekülatörün bilgi sahibi bir yatırımcı gibi görünerek sadece alım ve satım yoluyla kar elde edebileceğini belirtmişlerdir.

Allen ve Gorton (1992), pay senedi fiyat manipülasyonunu piyasanın mikro yapısı ve asimetrik bilgi dahilinde inceledikleri teorik çalışmada; satış yapan yatırımcının alım yapan yatırımcıdan daha az bilgiye sahip olmasının fiyatlarda asimetriye neden olduğunu ve bu durumun karlı bir manipülasyon fırsatı yarattığını tespit etmişlerdir. Jarrow (1992), ise para piyasasında büyük çapta alım satım yapan 
spekülatörleri incelediği çalışmada, pay senedi fiyatının büyük miktarda alım satım yapanların geçmişte birbiri ardına yaptıkları alım satımlara bağlı olması halinde manipülasyonun mümkün olabileceğini belirtmiştir. Gerard ve Nanda (1993), ikincil halka arzlarda manipülasyonu inceledikleri çalışmalarında, bilgili bir yatırımcının ikincil halka arz öncesinde yoğun bir şekilde açığa sattığı payları, halka arz esnasında tekrar düşük fiyatlardan satın alarak karlı bir manipülasyon fırsatı yakalayabileceğini tespit etmişlerdir. Felixson ve Pelli (1999), Finlandiya borsasında işlem gören menkul kıymetlerin kapanıştan 15 dakika öncesi ve 15 dakika sonrası getirilerini regresyon modeli kullanarak analiz ettikleri çalışmada, kapanış fiyatı noktasında zayıf manipülatif hareketler tespit etmişlerdir. Feng vd. (2003), pay senedi fiyat manipülasyonlarını Çin ikincil piyasada inceledikleri çalışmada, pay senedi fiyatlarındaki büyük değişimin manipülasyonun varlığına ilişkin tek başına kanıt olmada yetersiz olduğunu fakat fiyat ve hacim ilişkisindeki ani düşüşün piyasada daima manipülasyonun varlığına işaret ettiğini tespit etmişlerdir. Khwaja ve Mian (2005), Pakistan Karaçi Borsası'nda 21 Aralık 1998 - 31 Ağustos 2001 dönemi için 32 aylık periyotta pay senedi manipülasyonlarını inceledikleri çalışmada, şişirme ve indirme yöntemiyle kendi adına işlem yapan brokerların başka yatırımcılar adına işlem yapan brokerlardan en az \%50-\%90 arasında daha yüksek kümülatif anormal getiri elde ettikleri sonucuna varmışlardır. Jiang vd. (2005), New York Borsası'nda 1928 ve 1929 dönemi için havuz işlemine maruz kalmış pay senetlerinin havuz öncesi ve sonrası karakteristiklerini inceledikleri çalışmanın sonucunda, havuzlama esnasındaki pay senedi anormal devir hızının havuzlama işlemi öncesine göre daha yüksek ve daha oynak bir durum sergilediğini ve havuz işlemi gerçekleştirenlerin daha yüksek volatilite ve pay senedi devir hızına neden olduğundan spekülatif paylara daha çok ilgi duyduklarını tespit etmişlerdir.

Huang vd. (2005), Tayvan Borsasında 1991 - 2003 dönemi arasında 53 manipülasyon vakasına ilişin pay senetlerinde gözlemlenen; işlem hacmi, getiri ve volatilite artışının piyasanın etkin olmamasına neden olduğunu tespit etmişlerdir. Aggarwal ve Wu (2006), ABD'de Ocak 1990 - Ekim 2001 döneminde 142 borsa manipülasyon vakasını inceledikleri çalışmada, likit olmayan pay senetlerinin manipüle edilme olasılığının daha yüksek olduğunu, manipülasyonun; pay senedin likiditesini, volatilitesini, getirisini artırdığını ve manipülasyon dönemi boyunca pay senedi fiyatındaki yükselişin manipülasyon sonrası dönemde düştüğünü tespit etmişlerdir. Akyol ve Michayluk (2007), Borsa İstanbul'da BiST 30'da yer alan pay senetlerinin 1 Ocak 2005 - 31 Aralık 2005 dönemine ait verilerinden hareketle kapanış fiyatı manipülasyonunu inceledikleri çalışmada, hem sabah hem de öğleden sonraki işlem seanslarına ilişkin son işlem getirilerinin yüksek olduğunu ancak ikinci seanstaki getirilerin büyüklüğünün ilk seansta elde edilen getirilerden iki kat daha fazla olduğunu ve bu durumun kısmen fiyat manipülasyondan kaynaklandığını tespit etmişlerdir. Küçükkocaoğlu (2008a), 1 Ocak 2000 - 29 Mart 2002 döneminde IMKB`de gün için hisse senedi getirilerinin davranışı ve kapanış fiyatı manipülasyonunu IMKB Ulusal-30 endeksinde yer alan yirmi üç hisse senedi için OLS regresyon yöntemiyle incelediği çalışmada, pay senetlerinin çoğu için elde edilen sonuçların istatistiksel açıdan zayıf ve anlamsız olmasına rağmen büyük alıcı ve satıcılar aracılığıyla kapanış fiyatı manipülasyonunun mümkün olabileceğini belirtmiştir. Küçükkocaoğlu (2008b), hisse senedi fiyatını manipüle etmeye yönelik hareketlerin düşük sermayeli, halka açıklık oranı az ve günlük işlem hacmi sınırlı olan hisse senetlerinde görüldüğünü, Tek Fiyat Sistemi ile hisse senedinin açııştaki fiyatının arz ve talep açısından doğru bir şekilde belirlendiğini ve bunun etkin bir piyasanın oluşmasına ortam hazırladığını belirtmiştir. Ögüt vd. (2009), IMKB'de 1995 - 2004 arası 222 işlem bazlı manipülasyon vakası üzerinde pay senedi fiyat manipülasyonunun tespitine yönelik çok değişkenli istatistiksel teknikler ve veri madenciliği kullanarak yaptıkları çalışmada, pay senedi fiyat manipülasyonlarının tespiti noktasında veri madenciliğine dayalı tekniklerin çok değişkenli istatistiksel yöntemlere göre daha başarılı olduğunu tespit etmişlerdir. Kamışlı ve Girginer (2010), IMKB'de 1996 - 2005 döneminde işlem bazlı manipülasyonları finansal oranlar aracılığıyla analiz ettikleri çalışmalarında, işlem bazlı manipülasyonun belirlenmesinde aktif karlılık oranı ve pay başına defter değeri oranının etkili olduğu sonucuna ulaşmışlardır. Özcan (2011), açıış ve kapanış fiyatı manipülasyonunu incelediği çalışmada, açıış ve kapanışta gerçekleştirilen pay senedi fiyat manipülasyonlarını engelleme noktasında IMKB'de uygulanan açıış seansı uygulamasına ek olarak kapanış seansı uygulamasına geçilmesi gerektiğini ve bu seanslarda fiyat belirleme işleminin önceden belirlenen bir aralıkta rastgele bir zamanda yapılmasının manipülasyonla mücadelede gücünü arttırdığını belirtmiştir. Diaz vd. (2011), gün içi verileri kullanarak 
8'i manipüle edilmiş, 26 'sı benzer ve 31'i farklı pay olmak üzere kapanış fiyatı manipülasyonunu inceledikleri çalışmalarında, son çeyrek ve yıl sonunda kapanış saatlerinin yanı sıra manipülasyon için ön şartların yaygın olduğu yüksek likidite, getiri ve volatilitenin manipüle edilmiş örneklemlerdeki varlığını doğrulamışlardır. Comerton-Forde ve Putnins (2011), Amerika ve Kanada'da dava konusu olan vakalar üzerinden 1 Ocak 1997 - 1 Ocak 2009 döneminde kapanış fiyatı manipülasyonunu inceledikleri çalışmada, manipülasyonun olduğu durumda gün sonu getirilerde büyük artışlar, getirinin tersine dönmesi, işlem aktivitesi ve alım-satım arasındaki fiyat farklılarına ilişkin güçlü kanıtlar elde etmişlerdir. Roodposhti vd. (2011), Tahran Borsasında işlem gören şirketlerin fiyat manipülasyonunu tahmin ettikleri çalışmada; firma büyüklüğü, fiyat/kazanç oranı, bilgi şeffaflığı, pay likiditesi ve şirket ortaklık yapısı gibi değişkenlerin fiyat manipülasyonunun tespiti noktasında belirleyici değişkenler olduklarını tespit etmişlerdir. İmişiker ve Taş (2013), 1998 - 2006 dönemi için Borsa İstanbul'da işlem bazlı manipülasyonu panel probit regresyon yöntemi ile inceledikleri çalışmada; halka açıklık oranı düşük ve daha yüksek kaldıraç oranına sahip firmaların pay senedi fiyat manipülasyonuna daha yatkın olduklarını tespit etmişlerdir. Huang ve Cheng (2013), Tayvan Borsasında 1991'den 2010'a kadar olan dönemdeki manipülasyon vakalarının özelliklerini ve piyasaya olan etkilerini inceledikleri çalışmada, şişirme ve indirme tipi manipülasyonun; manipülasyon döneminde yüksek geçici fiyat etkilerine, artan volatiliteye, büyük işlem hacimlerine, kısa dönemli fiyat devamlılığına ve bu fiyat devamlıığının uzun dönemde tersine dönmesine yol açtığını tespit etmişlerdir. Kadıoğlu (2014), Borsa İstanbul'da 1 Kasım 2006 - 31 Mayıs 2012 döneminde farklı endekslerde yer alan 102 adet pay senedi için kapanış fiyatı manipülasyonunu incelediği çalışmasında, kapanış seansı uygulamasının kapanış fiyatı manipülasyonunu büyük ölçüde ortadan kaldırdığını tespit etmiştir. Comerton-Forde ve Putnins (2014), 1998 ve 2005 döneminde NYSE, AMEX, TSX ve TSX-V borsalarında işlem gören toplam 31 pay senedi için kapanış fiyatı manipülasyonunun geçerliliğini analiz ettikleri çalışmada, kapanış fiyatlarının \%1'inin manipüle edildiğini, asimetrik bilgi seviyesi yüksek ve likiditesi ise orta düşük seviyedeki payların manipüle edilme olasılığını yüksek olduğunu tespit etmişlerdir. İmişiker ve Taş (2014), Borsa İstanbul'da, 2003 - 2006 dönemi için işlem bazlı manipülasyon türlerinden olan kendinden kendine işlemlerin (wash sales) karlıığını araştırdıkları çalışmalarında, yatıımcıların önemli bir miktarının kendinden kendine işlem gerçekleştirdiklerini ve toplam işlemlerin \%30'unu oluşturan bu işlemlerden kar elde ettiklerini tespit etmişlerdir. Kong ve Wang (2014), Çin Şangay Borsası üzerinde bireysel bir yatırımcının 15 hisse senedi üzerinde gerçekleştirmiş olduğu kurgulu emirlere dayalı manipülasyonun fiyat, hacim, pay senedi devir hızı ve likidite üzerindeki etkilerini standart olay çalışması yöntemiyle analiz ettikleri çalışmada; pay senedinin fiyatı, devir hızı, işlem hacmi ve volatilitesinin manipülasyon döneminde daha yüksek olduğunu, manipülasyon sonrası dönemde ise düştüğünü tespit etmişlerdir. Chaturvedula vd. (2015), Hindistan Bombay Borsası ve Hindistan Ulusal Borsası üzerinde 2004 - 2012 dönemi için toplu satış ve alışların pay senedi fiyatı üzerindeki etkilerini analiz ettikleri çalışmada, 2004-2008 dönemi için yapılan incelemelerin yaklaşık \%80.5'inin piyasa dolandırıcılığı ile ilişkili olduğunu belirtmişlerdir. İmişiker vd. (2015), Borsa İstanbul'da 2003-2006 döneminde gün içi işlem verilerini kullanarak şişirme ve indirme tipi manipülasyonunu inceledikleri çalışmada, brokerlar tarafından gerçekleştirilen işlemlerin önemli bir yüzdesinin şişirme ve indirme tipi manipülasyona dayandığını ve brokerların nadir de bu işlemden yüksek karlar elde ettiklerini tespit etmişlerdir.

\section{YÖNTEM VE ANALIZ}

Literatürde temel amacı alım satım yaparak pay senedi fiyatını etkilemeye yönelik olan işlem bazlı manipülasyonun tespit edilmesi ve piyasa üzerindeki etkisinin belirlenmesi noktasında manipüle edilmiş pay senedine ilişkin getiri, işlem hacmi ve volatilite verilerinden hareket edildiği görülmektedir (Jiang vd. 2005; Huang vd. 2005; Aggarwal ve Wu, 2006; Öğüt vd. 2009; Huang ve Cheng, 2013).

$\mathrm{Bu}$ çalışmada işlem bazlı manipülasyonun pay senedi üzerindeki etkisi incelemek üzere Öğüt vd. (2009) tarafından yapılan çalışmada kullanılan yöntemde bazı değişikliklere gidilmiştir. Yapılan değişiklikler; içerisinde banka, gayrimenkul yatırım ortaklıkları ve sigorta şirketlerinin yer aldığı tüm endeksin kullanılması yerine manipüle edilmiş şirketin içinde yer aldığı endeks getirisi (sınai, hizmet ve teknoloji) kullanılmıştır. Ayrıca Türkiye'de etkisi incelenmeyen fakat yurt dışındaki çalışmalarda (Mei vd. 2004; Huang vd. 2005; Aggarwal ve Wu, 2006; Kong ve Wang, 2014) kullanılan ve manipülasyon dönemlerinde etkisinin olduğu tespit edilen pay senedi devir hızı değişkeni 
(turnover) kullanılmıştır. Son olarak her bir manipüle edilmiş pay senedinin karşısına manipüle edilmemiş başka bir pay senedi koymak yerine, manipüle edilmiş şirketin manipülasyon öncesi ve sonrası durumu dikkate alınarak aynı şirketler analize dahil edilmiştir. $\mathrm{Bu}$ amaçla manipülasyonun pay senedi üzerindeki etkisi; manipülasyon öncesi dönem, manipülasyon dönemi ve manipülasyon sonrası dönem olmak üzere üç dönemde incelenmiştir.

\subsection{Veri Seti ve Değişkenler}

Çalışmanın veri seti 2001 - 2014 dönemi için Borsa İstanbul'a (BIST) kota olan ve SPK tarafından işlem bazlı manipülasyon gerçekleştirdiği tespit edilen şirketler dikkate alınarak hazırlanmıştır. Bu amaçla 2001 - 2014 dönemi için SPK tarafından yayınlanan haftalık bültenler tek tek incelenmiş ve toplamda 273 adet manipülasyon vakasına ulaşılmıştır. Elde edilen verilerden hareketle ortalama manipülasyon süresi 40 gün olarak hesaplanmıştır. Toplam 273 vaka içerisinde en kısa manipülasyon dönemi 1 gün olarak gerçekleşirken, en uzun manipülasyon dönemi 229 gün olarak gerçekleşmiştir. Çalışmada manipülasyonun etkisini görebilmek için işlem bazlı manipülasyon yapan şirketlerin; manipülasyon öncesi, manipülasyon dönemi ve manipülasyon sonrası durumları çoklu lojistik regresyon yöntemi ile test edilmiştir. Bağımlı değişkenin üç kategorili bir değişken olması (manipülasyon öncesi dönem, manipülasyon dönemi ve manipülasyon sonrası dönem) bağımsız değişkenlerin ise sürekli bir değişken olması sebebiyle parametrik olmayan bir test yöntemi olan çoklu lojistik regresyon analizi kullanılmıştır. Analizlerde kullanılan bağımlı ve bağımsız değişkenler sırasıyla aşağıda verilmiştir:

Bağımlı değişkenler, her bir manipüle edilmiş şirket için sırasıyla;

0: Manipülasyon öncesi dönem

1: Manipülasyon dönemi

2: Manipülasyon sonrası dönem olacak şekilde kodlanmıştır.

Analizde kullanılan bağımsız değişkenler ise sırasıyla;

$X_{1}$ : Manipüle edilmiş bir pay senedinin ortalama günlük getirisi ile endeksin ortalama günlük getirisi arasındaki fark,

$\mathrm{X}_{2}$ : Manipüle edilmiş bir pay senedinin günlük işlem hacmindeki ortalama değişimi ile endeksin günlük işlem hacmindeki ortalama değişimi arasındaki fark,

$\mathrm{X}_{3}$ : Manipüle edilmiş bir pay senedinin ortalama günlük volatilitesi ile endeksin günlük ortalama volatilitesi arasındaki fark,

$\mathrm{X}_{4}$ : Manipüle edilmiş bir pay senedinin ortalama pay senedi devir hızı.

Her bir manipüle edilmiş pay senedine ilişkin günlük getiriler, günlük işlem hacmi ve endeks getirisi Finnet Analiz Expert programı yardımıyla elde edilmiştir. Elde edilen verilerin analizini gerçekleştirmek için Stata 11.2 istatistiksel analiz programı kullanılmıştır.

Her bir manipüle edilmiş pay senedine ilişkin günlük volatilite tahmini, Parkinson (1980) tarafından önerilen yönteme göre aşağıdaki gibi hesaplanmıştır;

$$
\tilde{\sigma}_{i, t} \approx \sqrt{0.361\left[\ln \left(S_{i, t}^{\text {Yüksek }}\right)-\ln \left(S_{i, t}^{\text {Düsük }}\right)\right]^{2}}
$$

Formülde yer alan $S_{i, t}^{\text {Yüksek }}$ ve $S_{i, t}^{\text {Düsük }}$ pay senedinin t günde gözlemlenen en yüksek ve en düşük fiyatını göstermektedir.

Son olarak her bir manipüle edilmiş pay senedine ilişkin günlük devir hızı oranı ise Lo ve Wang (2000) çalışmasında kullandığı yönteme göre hesaplanmıştır;

$\tau_{j t} \equiv \frac{X_{j t}}{N_{j}}$

$X_{j t}$ j pay senedinin $\mathrm{t}$ gündeki işlem hacmi ve $N_{j}$ j pay senedinin dolaşımdaki toplam pay senedi sayısını göstermektedir.

\section{2. Çoklu Lojistik Regresyon Analizi}

Niteliksel bağımlı değişkenin kategori sayısına ve bu kategorilerin sırasız (nomimal) veya sıralanabilir (ordinal) olmasına göre farklı lojistik regresyon yöntemleri kullanılmaktadır. Bağımlı değişken sayısının ikiden çok ve sırasız niteliksel değişken tipinde olması durumunda çok kategorili sırasız lojistik regresyon yöntemi kullanııırken, bağımlı değişken sayısı ikiden çok ve sıralanabilir niteliksel değişken ise sıralı lojistik regresyon yöntemleri kullanılmaktadır (Alpar, 2013). Çoklu lojistik regresyon yöntemi, cevap değişkenin üç ve daha fazla kategori içerdiği ve bu kategorilerinin herhangi bir hiyerarşi içermediği durumlarda cevap değişkeni ile açıklayıcı değişkenler arasındaki 
neden-sonuç ilişkilerini ortaya koymakta ve açıklayıcı değişkenlerin etki derecelerini belirlemek amacıyla kullanılan bir tekniktir.

$\mathrm{Bu}$ analiz yönteminde kategorik açıklayıcı değişkenler faktör olarak alınırken sürekli değişkenler ise ortak değişken olarak alınmaktadır. Kategorik değişkenlerin her bir kategorisi için modelde katsayılar hesaplanmakta ve bu katsayıların önemlilikleri test edilmektedir (Özdamar, 2013). Y çıktı değişkenin kategorilerinin 0,1 ve 2 olarak kodlanmasıyla oluşturulacak olan logit model için $Y=0$ üzerinden $Y=1$ ve $Y=2$ 'ye ait denklemler oluşturulur. 3 kategorili bir çıktı olması durumunda 2 logit fonksiyon elde edilmektedir. Böylelikle belirlenen çıktı kategorisinin hangisinin olacağına karar verilmesi önemlidir. Başka bir ifade ile $Y=0$ referans kategorisi seçilmek suretiyle, $Y=1$ ve $Y=2$ 'ye ait logit denklemler aşağıdaki gibi formüle edilmektedir (Hosmer ve Lemeshow, 2000).

$$
\begin{aligned}
& \left.g_{1} x\right)=\ln \left[\frac{P(Y=1 \mid x)}{P(Y=0 \mid x)}\right]=\beta_{10}+\beta_{11} x_{1}+\beta_{12} x_{2}+\ldots \ldots \ldots \ldots \ldots \ldots+\beta_{1 p} x_{p}=x^{\prime} \beta_{1} \\
& g_{2}(x)=\ln \left[\frac{P(Y=2 \mid x)}{P(Y=0 \mid x)}\right]=\beta_{20}+\beta_{21} x_{1}+\beta_{22} x_{2}+\ldots \ldots \ldots \ldots \ldots . . . . . . .+\beta_{2 p} x_{p}=x^{\prime} \beta_{2}
\end{aligned}
$$

Verilen her bir çıktı kategorisinin şartlı olasılıkları ise aşağıdaki gibi formüle edilmiştir:

$$
\begin{aligned}
& P Y=0 \mid x)=\frac{1}{1+e^{g_{1}(x)}+e^{g_{2}(x)}} \\
& P(Y=1 \mid x)=\frac{e^{g_{1}(x)}}{1+e^{g_{1}(x)}+e^{g_{2}(x)}} \\
& P Y=2 \mid x)=\frac{e^{g_{2}(x)}}{1+e^{g_{1}(x)}+e^{g_{2}(x)}}
\end{aligned}
$$

Çoklu lojistik regresyon yönteminden elde edilen modelin uygunluk değerleri Tablo 1'de verilmiştir.

Tablo 1: Çoklu Lojistik Regresyon için Kurulan Modelin Uygunluk Değerine Ait Veriler

\begin{tabular}{|l|c|l|c|}
\hline Log-Lik Intercept Only: & -899.763 & Log-Lik Full Model: & -681.684 \\
\hline D(305): & 1363.368 & LR(55): & 436.159 \\
\hline & & Prob > LR: & 0.000 \\
\hline McFadden's R2: & 0.242 & McFadden's Adj R2: & 0.226 \\
\hline Maximum Likelihood R2: & 0.413 & Cragg \& Uhler's R2: & 0.465 \\
\hline Count R2: & 0.538 & Adj Count R2: & 0.308 \\
\hline AIC: & 1.701 & AIC*n: & 1393.368 \\
\hline BIC: & -4029.932 & BIC': & -382.494 \\
\hline
\end{tabular}

Tablo 1'e göre; Akaika bilgi kriteri (AIC) 1393,368 ve Bayes bilgi kriteri (BIC) -382,494 olarak belirlenmiştir. Kurulan modellerde düşük değerli AIC ve negatif değerli BIC değeri logit modelin uyum iyiliğinin tatmin edici seviyede olduğunu göstermektedir. Çoklu lojistik modelin olabilirlik oran değeri (likelihood ra- tio) 436.159'dur ve $p<0,01$ değeri olarak hesaplanmış olup tüm bağımsız değişkenlerin birlikte yer aldığı model istatistiksel açıdan anlamlı çıkmıştır. Çoklu lojistik modelin McFadden's $R^{2}$ değeri 0.242 olup bu değer bağımsız değişkenlerin bağımlı değişken üzerindeki değişikliklerin \%24.2'sini açıklamaktadır. 
Tablo 2: Çoklu Lojistik Regresyon Modeli için Uyum İyiliği Testi Sonuçları

\begin{tabular}{|l|c|}
\hline \multicolumn{2}{|c|}{ Çok Durumlu Logit Modelin Uyum İyiliği Testi } \\
\hline Grup Sayısı & 10 \\
\hline Pearson $\chi^{2}$ test istatistiği & 16.053 \\
\hline Serbestlik Derecesi & 16 \\
\hline P $>\chi^{2}$ & 0.449 \\
\hline
\end{tabular}

Tablo 2'de çoklu lojistik regresyon modeli için uyum iyiliği test sonuçlarına yer verilmiştir. dedir

“ $\mathrm{H}_{0}$ : Kurulan modelin veri uyumu yeterli düzey-

$\mathrm{H}_{a}$ : Kurulan modelin veri uyumu yeterli düzeyde değildir" şeklinde hipotezler kurulmuştur. Kurulan modelde $\mathrm{P}=0.449>0.05$ olduğundan $\mathrm{H}_{0}$ hipotezi kabul edilmiştir. Böylece çoklu lojistik regresyon modelinin manipülasyon dönemlerine ait sınıflandırma analizi için yeterli olduğu ifade edilebilir.
Tablo 3: Çoklu Lojistik Regresyon Modeli ait Bağımsız Değişkenler için Wald Testi

\begin{tabular}{|c|c|c|}
\hline $\begin{array}{c}\text { Bağımsız } \\
\text { Değişken }\end{array}$ & $\chi^{2}$ & $\begin{array}{c}\text { Serbestlik } \\
\text { Derecesi }\end{array}$ \\
\hline $\mathbf{X}_{\mathbf{1}}$ & 44.487 & 0.000 \\
\hline $\mathbf{X}_{\mathbf{2}}$ & 46.036 & 0.000 \\
\hline $\mathbf{X}_{\mathbf{3}}$ & 67.372 & 0.000 \\
\hline $\mathbf{X}_{\mathbf{4}}$ & 11.449 & 0.003 \\
\hline
\end{tabular}

Tablo 3'te çoklu lojistik regresyon modelindeki bağımsız değişkenlere yönelik gerçekleştirilen Wald test istatistiği sonuçları yer almaktadır. Manipülasyon dönemi için modeldeki tüm bağımsız değişkenlerin bağımlı değişken üzerindeki etkisi \%1 önem seviyesinde istatistiksel açıdan anlamlı olarak tespit edilmiştir.

Tablo 4: Şirketlere ait Manipülasyon Vakasını Etkileyen Faktörlerin Çoklu Lojistik Regresyon Analizi

\begin{tabular}{|c|c|c|c|c|c|c|c|c|c|}
\hline & & & & & & & \multirow{2}{*}{\multicolumn{2}{|c|}{ Gözlem Sayısı }} & 819 \\
\hline & & & & & & & & & 436.16 \\
\hline & & & & & & & \multicolumn{2}{|c|}{$\mathbf{p}>\chi^{2}$} & 0.0000 \\
\hline & \multicolumn{2}{|c|}{ Log likelihood } & \multicolumn{2}{|c|}{-681.684} & & & \multicolumn{2}{|c|}{ Pseudo $\mathrm{R}^{2}$} & 0.2424 \\
\hline $\mathbf{Y}$ & $\begin{array}{l}\text { Bağımsıız } \\
\text { Değişken }\end{array}$ & Katsayı & Std. Hata & Wald & z & $P>Z$ & $\begin{array}{l}\text { Odds } \\
\text { Oranı }\end{array}$ & {$[95 \% \mathrm{Gi}$} & Aralığı] \\
\hline $\begin{array}{l}\text { Manipülasyon } \\
\text { Öncesi Dönem }\end{array}$ & \multicolumn{9}{|c|}{ Referans Kategorisi } \\
\hline \multirow{5}{*}{$\begin{array}{c}\text { Manipülasyon } \\
\text { Dönemi }\end{array}$} & $x_{1}$ & 46.376 & 10.214 & 20.616 & 4.54 & 0.000 & $1.38 \mathrm{e}+20$ & 26.356 & 66.396 \\
\hline & $x_{2}$ & 0.656 & 0.160 & 16.810 & 4.11 & 0.000 & 1.9267 & 0.342 & 0.969 \\
\hline & $x_{3}$ & 80.958 & 10.218 & 62.775 & 7.92 & 0.000 & $1.44 \mathrm{e}+35$ & 60.930 & 100.986 \\
\hline & $X_{4}$ & 0.541 & 0.164 & 10.882 & 3.29 & 0.001 & 1.718 & 0.219 & 0.863 \\
\hline & Sabit & -3.054 & 0.273 & 125.145 & -11.18 & 0.000 & & -3.589 & -2.519 \\
\hline \multirow{5}{*}{$\begin{array}{l}\text { Manipülasyon } \\
\text { Sonrası Dönem }\end{array}$} & $\mathrm{X}_{1}$ & -11.297 & 10.098 & 1.252 & -1.12 & 0.263 & 0.000 & -31.089 & 8.49 \\
\hline & $x_{2}$ & -0.696 & 0.195 & 12.739 & -3.55 & 0.000 & 0.498 & -1.08 & -0.312 \\
\hline & $x_{3}$ & 22.599 & 9.22 & 6.008 & 2.45 & 0.014 & $6.53 e+09$ & 4.52 & 40.678 \\
\hline & $x_{4}$ & 0.348 & 0.163 & 4.558 & 2.14 & 0.033 & 1.417 & 0.029 & 0.668 \\
\hline & sabit & -0.203 & 0.194 & 1.095 & -1.05 & 0.295 & & -0.583 & 0.177 \\
\hline
\end{tabular}


Tablo 4'te şirketlere ait bağımsız ve bağımlı değişkenler için çoklu lojistik regresyon analizine ait sonuçlara yer almaktadır. Tablo 4'te görüldüğü üzere modeldeki gözlem sayısı 819'dur. Çoklu lojistik regresyon analizine göre $\chi^{2}$ değeri istatistiksel açıdan anlamlı $(p<0.01)$ olduğu tespit edilmiştir. Model sonucunda log olabilirlik değeri - 681.68 olarak gerçekleşmiştir.

Tablo 4'te ilk sütunda çoklu lojistik regresyon analizinin $\beta$ katsayıları yer almaktadır. Manipülasyon öncesi durum referans kategorisi olarak dikkate alındığında; manipülasyon dönemi için bağımsız değişkenlerin tamamının \%1 önem seviyesinde istatistiksel olarak anlamlı olduğu tespit edilmiştir. $\mathrm{X}_{1}$ değişkeni "manipüle edilmiş bir pay senedinin ortalama günlük getirisi ile endeksin ortalama günlük getirisi arasındaki fark" ile $\mathrm{X}_{3}$ değişkeni "manipüle edilmiş bir pay senedinin ortalama günlük volatilitesi ile endeksin günlük ortalama volatilitesi arasındaki fark" değerlerinin üstel lojistik değerleri \%100'ün üzerinde gerçekleşmiştir. Dolayısıyla bu değişkenler bir birim artırıldığında, manipülasyon dönemindeki bir şirketin odd'su, manipülasyon öncesindeki bir şirketin odd'suna göre \%100 üzerinde bir artışa neden olacaktır. $X_{2}$ değişkeni “manipüle edilmiş bir pay senedinin günlük işlem hacmindeki ortalama değişimi ile endeksin günlük işlem hacmindeki ortalama değişimi arasındaki fark" değeri bir birim artırıldığında; manipülasyon dönemindeki bir şirketin odd'su, manipülasyon öncesindeki bir şirketin odd'suna göre \%92.7 oranında artacaktır. $X_{4}$ değişkeni "manipüle edilmiş bir pay senedinin ortalama pay senedi devir hızı" değeri bir birim artırıldığında manipülasyon dönemindeki bir şirketin odd'su, manipülasyon öncesindeki bir şirketin odd'suna göre \%71.8 oranında artacaktır. Manipülasyon sonrası dönemi için bağımsız değişkenlerden $\mathrm{X}_{2^{\prime}} \mathrm{X}_{3}$ ve $\mathrm{X}_{4}$ değişkenlerinin \% 5 önem seviyesinde istatistiksel olarak anlamlı olduğu tespit edilmiştir. $X_{1}$ değişkeni“manipüle edilmiş bir pay senedinin ortalama günlük getirisi ile endeksin ortalama günlük getirisi arasındaki fark" bir birim artırıldığında; manipülasyon sonrasındaki bir şirketin odd'su, manipülasyon öncesindeki bir şirketin odd'suna göre $\% 100$ oranında azalacaktır. $X_{2}$ değişkeni "manipüle edilmiş bir pay senedinin günlük işlem hacmindeki ortalama değişimi ile endeksin günlük işlem hacmindeki ortalama değişimi arasındaki fark" değeri bir birim artırıldığında; manipülasyon sonrasındaki bir şirketin odd'su, manipülasyon öncesindeki bir şirketin odd'suna göre \% $50.2(1-0.498=0.502 * 100)$ oranında azalacaktır. $X_{3}$ değişkeni "manipüle edilmiş bir pay senedinin ortalama günlük volatilitesi ile endeksin günlük ortalama volatilitesi arasındaki fark" değeri bir birim artırıldığında; manipülasyon sonrasındaki bir şirketin odd'su, manipülasyon öncesindeki bir şirketin odd'suna göre \% 100 üzerinde bir artışa neden olacaktır. $\mathrm{X}_{4}$ değişkeni "manipüle edilmiş bir pay senedinin ortalama pay senedi devir hızı" değeri bir birim artırıldığında; manipülasyon sonrasındaki bir şirketin odd'su, manipülasyon öncesindeki bir şirketin odd'suna göre \%41.7 oranında bir artışa neden olacaktır.

Tablo 5: Bir Şirketin Manipülasyon Öncesi, Dönemi ve Sonrası için Bağımsız Değişkenlerin Bağımlı Değişken Üzerindeki Marjinal Etkileri

\begin{tabular}{|l|c|c|c|}
\hline & $\begin{array}{c}\text { Manipülasyon } \\
\text { Öncesi }\end{array}$ & $\begin{array}{c}\text { Manipülasyon } \\
\text { Dönemi }\end{array}$ & $\begin{array}{c}\text { Manipülasyon } \\
\text { Sonrası }\end{array}$ \\
\hline $\mathbf{X}_{\mathbf{1}}$ & -5.57 & 12.62 & -7.05 \\
\hline $\mathbf{X}_{\mathbf{2}}$ & -0.037 & 0.236 & -0.199 \\
\hline $\mathbf{X}_{\mathbf{3}}$ & -13.02 & 17.5 & -4.478 \\
\hline $\mathbf{X}_{\mathbf{4}}$ & -0.102 & 0.096 & 0.007 \\
\hline
\end{tabular}

Tablo 5'te yer alan değerler; manipülasyon öncesi, manipülasyon dönemi ve manipülasyon sonrası dönem için bağımsız değişkenlerin bağımlı değişken üzerindeki marjinal etkilerini göstermektedir. Diğer tüm bağımsız değişkenler sabit kalmak şartıyla $X_{3}$ değişkenindeki "manipüle edilmiş bir pay senedinin ortalama günlük volatilitesi ile endeksin günlük ortalama volatilitesi arasındaki fark" bir birimlik artış, bir şirketin manipülasyon dönemine düşme olasılığını 17.5 kat arttırmış olduğundan en fazla etki eden değişken olmuştur. Bir şirketin manipülasyon dönemine düşme olasılığını sırasıyla $X_{1}$ değişkeni bir birimlik artış ile "manipüle edilmiş bir pay senedinin ortalama günlük getirisi ile endeksin ortalama günlük getirisi arasındaki fark" 12.62 kat, $\mathrm{X}_{2}$ değişkeni "manipüle edilmiş bir pay senedinin günlük işlem hacmindeki ortalama değişimi ile endeksin günlük işlem hacmindeki ortalama değişimi arasındaki fark" bir birimlik artış ile 0.236 kat ve $X_{4}$ değişkeni "manipüle edilmiş bir pay senedinin ortalama pay senedi devir hızı" bir birimlik artış ile 0.096 kat artırmaktadır. $X_{1}$ ve $\mathrm{X}_{2}$ değişkenlerindeki bir birimlik artışın bir şirketin manipülasyon öncesindeki etkisinin, manipülasyon sonrasındaki etkisine göre daha fazla olduğu buna karşın $X_{3}$ ve $X_{4}$ değişkenlerindeki bir birimlik artışın manipülasyon öncesindeki etkisinin, manipülasyon sonrasındaki etkisine göre daha az olduğu söylenebilir. 
Tablo 6: Şirketler için Çoklu Lojistik Regresyon Analizi Sınıflandırma Başarı Sonucu

\begin{tabular}{|c|c|c|c|c|}
\hline \multirow{2}{*}{ Tahmin Edilen Grup } & \multicolumn{3}{|c|}{ Gözlenen Grup } \\
\cline { 2 - 5 } & $\begin{array}{c}\text { Manipülasyon } \\
\text { Dönemi }\end{array}$ & $\begin{array}{c}\text { Manipülasyon } \\
\text { Öncesi ve } \\
\text { Sonrası }\end{array}$ & Toplam & $\begin{array}{c}\text { Doğruluk } \\
\text { Yüzdesi }\end{array}$ \\
\hline Manipülasyon Dönemi & 198 & 75 & 273 & $72.53 \%$ \\
\hline Manipülasyon Öncesi ve Sonrası & 68 & 478 & 546 & $87.55 \%$ \\
\hline Toplam & 266 & 553 & 819 & $82.54 \%$ \\
\hline
\end{tabular}

Tablo 6'ya göre şirketlerin; manipülasyon dönemi, manipülasyon öncesi ve sonrası olarak sınıflandırma işlemi çoklu lojistik regresyon analizi ile gerçekleştirilmiştir. Tablo 6'ya göre üç dönem için toplam 819 vakanın ele alındığı analiz aşamasında; manipülasyon dönemine ait 273 vakanın 198 'i, manipülasyon öncesi ve sonrası dönemine ait 546 vakanın ise 478 'i doğru olarak sınıflandırılmıştır. Manipülasyon dönemindeki şirketler için $\% 72.53^{\prime}$ lük ve manipülasyon öncesi ve sonrasındaki şirketler \%87.55'lik doğru sınıflandırma başarı ile tespit edilmiştir.

Son olarak çoklu lojistik regresyon analizinin yanlış sınıflandırma sonuçları I. Tip ve II. Tip hata ile açıklanmıştır. Bir hipotez testi sonucunda örneklem istatistiğine göre dört durumdan birisi söz konusudur (Serper, 2000);

$\mathrm{H}_{0}$; gerçekte doğrudur ve reddedilmemiştir,

$\mathrm{H}_{0 ;}$ gerçekte doğrudur, fakat reddedilmiştir,

$\mathrm{H}_{0^{\prime}}$ gerçekte yanlıştır, fakat reddedilmemiştir,

$\mathrm{H}_{0}$; gerçekte yanlıştır ve reddedilmiştir.

$a$ : Gerçekte doğru olan sıfır hipotezinin reddedilme olasılığını (1. Tip hata olasılığını),

$\beta$ : Gerçekte yanlış olan sıfır hipotezin reddedilmeme olasılığını (2. Tip hata olasılığını),

1- $a$ : Gerçekte doğru olan sıfır hipotezin reddedilmeme olasılığını,

2- $\beta$ : Gerçekte yanlış olan sıfır hipotezin reddedilme olasılığını göstermektedir (Serper, 2000; Turanlı ve Güriş, 2015; Başar ve Oktay, 2007).

Tablo 6'da yer alan verilerden hareketle araştırmada I. Tip hata oranı (gerçekte manipülasyon döneminde olan vakaların, manipülasyon olmayan dönemde değerlendirilme olasılığı) \%25.5 (68/266=\% 25.5) olarak gerçekleşirken, II. Tip hata oranı (gerçekte manipülasyon döneminde olmayan vakaların, manipülasyon döneminde değerlendirilme olasılığı) ise $\% 13.6(75 / 553=\%$ 13.6) olarak gerçekleşmiştir.
Sonuç olarak testin gücünü gösteren) $(1-\beta) \% 86.4$ $(1-0.136=0.864)$ olarak gerçekleşmiş, testin güvenirlik düzeyini gösteren $(1-a)$ ise $\% 74.5(1-0.255=0.745)$ olarak gerçekleşmiştir.

\section{SONUÇ}

Pay senedi fiyatlarının borsalarda yapay bir şekilde değişimi, sermaye piyasalarında faaliyet gösteren katılımcılar açısından manipülasyonu önemli bir olgu haline getirmiştir. Manipülasyon, piyasada arz ve talebin serbest bir şekilde oluşmasını engelleyerek piyasa etkinliğine zarar vermektedir. Çünkü bir piyasanın etkin olması hem piyasada işlem gören varlıkların gerçek değerini yansıtması bakımından hem de piyasa katılımcılarının bu ortamda alacağı yatırım kararları açısından büyük önem arz etmektedir. Dolayısıyla etkin olmayan bir piyasada ortaya çıkabilecek manipülatif girişimler piyasaya olan güveni azaltmakla birlikte finansal piyasaların gelişimini de olumsuz etkilemektedir.

Bu çalışmada işlem bazlı manipülasyonun; pay senedi getirisi, işlem hacmi, volatilite ve pay senedi devir hızı değişkenleri üzerindeki etkisi incelenmiştir. Bu amaçla 2001-2014 dönemi için toplam 273 adet manipülasyon vakası; manipülasyon öncesi dönem, manipülasyon dönemi ve manipülasyon sonrası dönem olmak üzere çoklu lojistik regresyon yöntemi ile analiz edilmiştir. Elde edilen bulgulara göre manipülasyon döneminde pay senetlerinin getirisinin, volatilitesinin, işlem hacminin ve devir hızının manipülasyon öncesi döneme göre belirgin bir şekilde artış göstermesi literatürde daha önce yapılmış çalışmaları destekler niteliktedir. Özellikle volatilite değişkeni, manipülatif girişimlerin etkisiyle bir şirketin manipülasyon dönemine düşme olasılığını etkileyen en önemli değişken olmuştur. Bu durum fiyat oluşum sürecine zarar vermekle birlikte etkin bir piyasanın oluşması yönünde de büyük bir engel teşkil etmektedir. Son olarak benzer bir şekilde manipülatif girişimlerin etkilediği bir diğer değişken olan 
ve konu bağlamında bu çalışma ile etkisi Türkiye'de ilk kez sınanan pay senedi devir hızı değişkeni piyasa düzenleyici kurumlara ve bu konudaki araştırmacılara yol gösterebilir. Bununla birlikte ileride yapılacak çalışmalarda farklı değişkenler kullanılarak işlem bazlı manipülasyonun pay senedi getirileri üzerindeki etkilerine odaklanılabilir.

\section{KAYNAKÇA}

Aggarwal, R.K.ve Wu, G. (2006) "Stock Market Manipulations." The Journal of Business, 79(4): 19151953.

Akyol, A., ve Michayluk, D. (2007) "Is there closing price manipulation on the Istanbul Stock Exchange" Australian School of Business. Working Paper.

Allen, F. ve Gale, D. (1992) "Stock-Price Manipulation" The Review of Financial Studies, 5(3): 503-529.

Allen, F., ve Gorton, G. (1992)“'Stock price manipulation, market microstructure and asymmetric information" European Economic Review, 36(2-3): 624-630.

Alpar, R. (2013) Çok Değişkenli İstatistiksel Yöntemler. 4. Baskı, Ankara, Detay Yayıncılık.

Başar, A. ve Oktay, E. (2007) Uygulamalı İstatistik-I: Kısa Teorik Bilgiler ve Çözülmüş Problemler. Aktif Yayınları, 4. Baskı, Ankara.

Chaturvedula, C., Bang, N. P., Rastogi, N., ve Kumar, S. (2015) "Price manipulation, front running and bulk trades: Evidence from India" Emerging Markets Review, 23: 26-45.

Comerton-Forde, C. ve Putninš̌, T. J. (2011) “Measuring closing price manipulation" Journal of Financial Intermediation, 20: 135-158.

Comerton-Forde, C. ve Putninšs, T. J. (2014) "Stock Price Manipulation: Prevalence and Determinants" Review of Finance, 18(1): 23-66.

Constable, P. (2011) "Ferocious Beast or Toothless Tiger? The Regulation of Stock Market Manipulation in Australia" Macquarie Journal of Business Law, (8): 54-78.

de Brouwer, G. (2001) Hedge Funds in Emerging Markets. Cambridge University Press.

Diaz, D., Theodoulidis, B., ve Sampaio, P. (2011) "Analysis of stock market manipulations using knowledge discovery techniques applied to intraday trade prices." Expert Systems with Applications, 38(10): 12757-12771.

Felixson, K. ve Pelli, A. (1999) “Day end returns - Stock price manipulation." Journal of Multinational Financial Management, 9(2): 95-127.

Feng, Z., Rongqiu, C., ve Xinping, X. (2003) "Fractal character of stock price-volume relation and regulation of stock price manipulation" Fractals, 11(2): 173-181.

Fischel, D. R. ve Ross, D. J. (1991) "Should the Law Prohibit "Manipulation" in Financial Markets?" Harvard Law Review, 105(2): 503-553.

Gerard, B. ve Nanda, V. (1993) "Trading and Manipulation Around Seasoned Equity Offerings." Journal of Finance, 48(1): 213-245.

Hosmer, D. W. ve Lemeshow, S. (2000) Applied Logistic Regression. New York: John Wiley \& Sons, Inc.

Huang, Y. C., Chen, R. C., ve Cheng, Y. J. (2005) "Stock manipulation and its impact on market quality" working paper, National Kaohsiung First University of Science and Technology, Kaohsiung 811, Taiwan, ROC h ttp://www. finance. nsysu. edu. tw/SFM/14thSFM/ FullPapers/060. pdf.

Huang, Y. C. ve Cheng, Y. J. (2013) "Stock manipulation and its effects: pump and dump versus stabilization." Review of Quantitative Finance and Accounting, 44(4): 791-815.

İmişiker, S. ve Taş, B. K. O. (2013) "Which firms are more prone to stock market manipulation?" Emerging Markets Review, 16: 119-130.

İmişiker, S. ve Taş, B. K. O. (2014) "Wash Sales as a Stock Market Manipulation Tool" Available at SSRN 2476874.

İmişiker, S., Özcan, R., ve Taş, B. K. O. (2015) "Price manipulation by intermediaries." Emerging Markets Finance and Trade, 51(4), 788-797.

IOSCO (2000) "Investigating and Prosecuting Market Manipulation"

Jarrow, R. A. (1992) "Market Manipulation, Bubbles, Corners, and Short Squeezes." The Journal of Financial and Quantitative Analysis, 27(3): 311-336.

Jiang, G., Mahoney, P. G., ve Mei, J. (2005) "Market manipulation: A comprehensive study of stock pools" Journal of Financial Economics, 77(1): 147-170.

Kadıoğlu, E. (2014) "Borsa Istanbul'un Mikro Yapisindaki Değişikliklerin Gün İçi Getiri, Volatilite ve Kapaniş Fiyatina Etkisi", Yayınlanmamış Doktora Tezi, Başkent Üniversitesi Sosyal Bilimler Enstitüsü.

Kamışlı, M. ve Girginer, N. (2010) "Işlem Bazlı Manipülasyonun İstatistiksel Sınınflandırma 
Analizleriyle Belirlenmesi." Istanbul University Econometrics \& Statistics e-Journal, 11(1): 1-30.

Khwaja, A. I. ve Mian, A. (2005) "Unchecked intermediaries: Price manipulation in an emerging stock market." Journal of Financial Economics, 78(1): 203-241.

Korsmo, C. (2014) "High-Frequency Trading: A Regulatory Strategy." University of Richmond Law Review, 48(2).

Küçükkocaoğlu, G. (2008a) "Intraday Stock Returns and Close End Price Manipulation in the Istanbul Stock Exchange" Frontiers in Finance and Economics. $5(1)$.

Küçükkocaoğlu, G. (2008b) "Sıngle-Prıce Auctıon System For Istanbul Stock Exchange" Borsa Istanbul Review, 8(29): 75-91.

Lo, A. W. ve Wang, J. (2000) "Trading volume: definitions, data analysis, and implications of portfolio theory." Review of Financial Studies, 13(2), 257-300.

Mei, J., Wu G. ve Zhou C. (2004) "Behavior based manipulation: theory and prosecution evidence" $\mathrm{NYU}$ Working paper.
Öğüt, H., Doğanay, M. M., ve Aktaş, R. (2009)“Detecting stock-price manipulation in an emerging market: The case of Turkey." Expert Systems with Applications, 36(9): 11944-11949.

Ozcan, R. (2011) "Strategic measures to prevent opening and closing price manipulation in stock markets" iktisat işletme ve Finans, 26(306): 53-67.

Özcan, R. (2013) "Hisse Senedi Piyasalarında Manipülasyon Stratejileri." IMKB Dergisi, (49): 19-41.

Özdamar, K. (2013) Paket Programlar İle İstatiksel Veri Analizi 1. Genişletilmiş 9. Baskı, Eskişehir, Nisan Kitabevi.

Serper, Ö. (2004) Uygulamalı İstatistik 2. 4. Baskı, Bursa, Ezgi Kitabevi.

Parkinson, M. (1980) "The extreme value method for estimating the variance of the rate of return." Journal of Business, 61-65.

Roodposhti, F. R., Shams, M. F., ve Kordlouie, H. (2011) "Forecasting stock price manipulation in capital market." World_Academy of Science, Engineering and Technology, 80: 151-161.

Turanlı, M. ve Güriş, S. (2015). Temel İstatistik. 5. Baskı, İstanbul, Der Yayınları. 
